\title{
Income Inequality and Economic Downturn in Europe: A Multi-Level Analysis of their Consequences for Political Participation
}

\author{
Andrea Filetti and Jan Germen Janmaat
}

\begin{abstract}
The ongoing rise of inequality and the outbreak of the economic crisis since 2008 have fueled the debate about the effects of macro-economic processes on democracy in general, and on political participation in particular. Whereas the effect of economic disparity is well documented in the literature, the implications of the economic downturn have not been sufficiently evaluated so far. The article addresses this gap by offering a comprehensive overview of the impact of these macroeconomic factors on individual political participation in Europe. Using data from the first six rounds of the European Social Survey (ESS), it shows that income inequality reduces participation and enlarges the participatory gap between better- and worse-off. In contrast, economic contraction has no effect on the overall level of participation and makes the poor participate more and the rich less.
\end{abstract}

Keywords: participation, economic crisis, inequality, ESS, democracy, political equality.

\section{Introduction}

Rising inequality and the recent economic downturn have renewed scholarly attention in the effects of macro-economic conditions on democracy. Despite the fact that democracy is essentially a political revolution, rather than an economic one (Przeworski 2008) and that it has no "intrinsic association with (...) the private realm of the economic market" (Bermeo 2012, 16), scholars are concerned about the vitality and stability of democracy under conditions of widening disparities and economic crisis (e.g. Thomassen 1989; Inglehart and Welzel 2005). One way of looking at this is to evaluate the effect of these conditions on citizen participation. Few doubts exist about the importance of citizens' participation for democracy. According to Schlozman et al. (1999), this is because political participation contributes to the development of an individual's sense of political efficacy, to the spread of democratic orientations that facilitate cooperation within communities, and to making government more responsive to the interests of citizens. For these reasons, studies on democratic qualities routinely include participation as a fundamental outcome of investigation (e.g. Morlino 2011).

Several studies examine the link between economic inequality and political participation. In particular, Solt's series of articles represents a fundamental contribution to start with: inequality is 
found to reduce overall levels of engagement and, most importantly from the democratic point of view, to enlarge the participatory gap between the rich and the poor, no matter if studied from a global comparative perspective (2008), with a special focus on the US (2010), or focusing on Europe alone (2015). The contribution of Solt's analyses is fundamental, but there is still room for further research. Firstly, his findings are not unanimously confirmed by other authors. For instance, Anderson and Beramendi (2008) demonstrate that income inequality significantly lower civic participation in 18 OECD democracies, but it does so to a similar degree for both the rich and the poor. Secondly, and most importantly, all previous studies do not cover, to our knowledge, a period of time that includes the recent economic crisis. This is an important limitation that needs to be addressed and this article seeks to do so. On the one hand, we test Solt's findings on the effect of economic inequality on an unprecedented dataset created with the first six rounds of the European Social Survey (ESS). This allows us to look at a ten-year period of time from 2002 to 2012, thus including three rounds before the economic crisis, and three rounds after its outbreak. To our knowledge existing research has not yet examined the effect of inequality in periods that include a major recession. On the other hand, we also pay attention to the effect of the so-called Great Recession itself, both in how it influences participation directly and in how it magnifies or diminishes the participation gap between rich and poor. Analyzing the impact of both macro factors is particularly important, since predictions about their effects are made with reference to competing theoretical perspectives, as we will explain in greater detail below.

The evidence from our analyses is mixed. On the one hand, Solt's findings about the detrimental effect of income inequality are partially confirmed, although our results also show a different pattern on one form of political participation which needs further attention. On the other hand, the economic downturn apparently counteracts this tendency by fostering the participation of the poor and reducing the participation of the rich.

The article is structured as follows: in the next section, we present in more details the relevant literature and the working hypotheses. We do so by distinguishing between two main foci, i.e. inequality and crisis, even though we will later show that the same theoretical models are useful to interpret empirical patterns related to both. Data and variables are introduced in the third section; the empirical analysis will be reported on in the fourth one. The main findings are summarized and discussed in the final paragraph.

\section{Literature review and working hypotheses}




\subsection{Inequality and participation}

Traditionally, studies on economic inequality and political participation pay attention to individuallevel predictors and to their impact on citizens' likelihood to participate. Political participation is taken as a costly behavior, associated with undetermined gains and certain costs, in terms of "time to take part, money to contribute to campaigns and other political causes, and skills to use time and money effectively" (Verba, Schlozman, and Brady 1995, 16). Individuals thus make decisions about participating to the political process just as they make decisions to consume any other good. Since intellectual and material resources are necessary for engaging in the political process, larger amounts of resources are expected to increase the likelihood of engagement (Ansolabehere et al. 2003, 117-18). Verba and associates cover a broad range of such factors, e.g. social, economic and educational resources (Verba, Nie, and Kim 1978) and family background (Verba, Burns, and Schlozman 2003). In similar terms, Marsh and Kaase (1979) show that advantaged citizens are more likely to engage in conventional and unconventional forms of participation. Levinson (2012) underlines the importance of ethnic and educational backgrounds, while Loose and Jae (2013) demonstrate that higher income reduces the opportunity costs of political participation in the US.

Besides its undisputed merits, this theoretical perspective remains silent about the impact of macro-level conditions such as economic inequality on individual participation. The relative power theory, as developed by Solt on the basis of Schattschneider's original hypothesis (1960), provides the rationale for examining the effect of economic inequality. The point of departure is the assumption that money and personal affluence can be used to influence others and to steer political decisions. The more concentrated wealth and income are, the more power is in the hands of the rich. On this basis, the well-off are expected to prevail more easily in occasionally open conflicts on issues regarding their interests in more unequal countries (Goodin and Dryzek 1980). Furthermore, they manage to prevent some issues to become part of the public debate by excluding them from the agenda (Bachrach and Baratz 1970; Schattschneider 1960). How does it matter for political engagement? If poor people perceive the political system to be incapable to defend their interests, they can rationally decide to abandon their engagement in politics (Gaventa 1980; Pateman 1971; Schattschneider 1960; Offe 2013). At the same time, also the rich have reduced incentives to mobilize politically in defense of their interests, given the withdrawal of the main contenders (and their possibility to steer politics by other means). All in all: following Solt's perspective, economic inequality is expected to decrease political engagement, albeit with a stronger impact for the poor than for the rich (Schattschneider 1960; Uslaner and Brown 2005). Put differently, as inequality 
increases, the disparity in participation between the rich and the poor will widen. The first goal of this article is to test this hypothesis, which includes two distinct statements:

$\mathrm{H}_{1}$ ) Inequality depresses overall participation and increases the participatory gap between the rich and the poor.

Further empirical evidences of such patterns are reported, among others, by Lancee and Werfhortst (2012; see also Toth et al. 2014) and Karakoç (2013). However, even though inequality is always found to depress participation, its differential effect on the rich and the poor (i.e. its asymmetrical impact) is challenged by further studies. On the one hand, Anderson and Beramendi (2008) show that inequality significantly lower participation at both ends of the income distribution, thus leaving the participatory gap unaltered (equal impact). On the other, Ansolabehere et al. (2003) find that inequality encourages engagement for rich individuals (their focus is on campaign contribution) and has an opposite effect at the other extreme of the income distribution (symmetrical impact).

This means we have good reasons to replicate the analyses on a range of outcomes, all the more so in order to test the predictive capability of Solt's model in times of economic turmoil. As a matter of fact, no studies among those mentioned above include data collected during the ongoing crisis, and it is thus important to check whether the relationship between inequality and participation still holds under these circumstances.

\subsection{Crisis and participation}

Our second aim is to assess whether the crisis itself has an impact on citizens' participation. So far this question attracted little attention. A notable exception is the study by Kern et al. (2015) who test the effects of indicators associated with the economic downturn (first and foremost unemployment rates) on changes to participation in Europe. Their main working hypothesis builds on the so-called grievance theory, which expects to see higher levels of political animosity and participation in response to rising poverty and unemployment. Since 2008, most of European countries faced enormous economic problems, in terms of economic contraction and rising unemployment rates. When citizens perceive their own situation as falling short of expectations and think they don't get what they deserve, feelings of relative deprivation arise and these, in turn, are expected to create a strong incentive for collective action and protest behavior (Gurr 1970, Klandermans et al. 2008). Their analysis provides support for this model and indeed it shows that 
rising unemployment levels encourage specific forms of non-institutionalized participation. Hence, our working hypothesis in this respect goes as follows:

$\left.\mathrm{H}_{2}\right)$ The economic crisis encourages political participation.

Notwithstanding its merit, their analysis can be improved. First of all, the authors do not control the effect of the crisis for other factors at the country-level. Their dataset includes both democratic and non-democratic countries (the Russian Federation) and no control for this and for different participation propensities in Eastern and Western Europe is included in their model. Furthermore, and most importantly, they do not control for additional economic factors, such as inequality or country-specific levels of wellbeing ${ }^{\mathrm{i}}$. Our analysis does so, in order to isolate the actual impact of the economic crisis from that of other factors and to gain a more robust assessment of its consequences. Second, they principally focus on the main effect of the crisis and present no evidence for its contingent effect, i.e. the differential effect of the crisis depending on individual economic resources. As economic crises often have more dramatic effects on the poor (cf. Baldacci et al 2012), for instance because of cuts to welfare programs on which they disproportionately depend, they are likely to feel more deprived than other groups and may thus, following the logic of the grievance theory, be more inclined to become politically active than more privileged groups (cf. Foster and Matheson 1995). This would lead one to surmise that the greater the economic downturn is, the smaller is the difference in political participation between the rich and the poor (or, even more spectacularly, the greater is this difference to the benefit of the poor):

$\left.\mathrm{H}_{3}\right)$ The economic crisis reduces the participatory gap between the rich and the poor.

Thus, while relative power theory expects lower levels of and greater social gaps in participation in the more unequal countries, grievance theory anticipates opposite outcomes with respect to the economic crisis, i.e. higher levels of and greater equality in participation in the more crisis-afflicted countries.

\section{Data and variables}

\subsection{Data}

As already mentioned, we focus on democratic European countries. All survey data are drawn from the European Social Survey (ESS), which is a biennial, high-quality survey of values, attitudes and 
behavior among European populations. More specifically, we create a pooled dataset using the first six rounds: this allows us to cover a period of time included between 2002 and 2012, with three rounds collected before the economic crisis (2002, 2004 and 2006) and three rounds completed after the beginning of the Great Recession (2008, 2010 and 2012). This leaves us 248.741 individuals, nested in 130 country-year, nested in 29 different countries ${ }^{\text {ii }}$.

\subsection{Dependent Variables}

The ESS offers a vast range of indicators on several forms of political participation and some descriptive statistics are included in Appendix A. Unsurprisingly, there is a great deal of variation across different types of mobilization. Our first dependent variable is electoral participation, which is measured with the classic question on whether the respondent has voted or not in the most recent elections for the national parliament. Electoral participation is by far the most widely diffused across all European populations: with $77.3 \%$ of respondents declaring their participation in the last national elections, Europe is by and large in line (albeit slightly above) with other countries in the world, given the figure provided by Blais $(2007,622-623)$ of a mean of $75.5 \%$. This data is per se quite telling about the resilience of electoral participation as the main channel of political engagement and can explain why this form of participation continues to attract most scholarly attention (Solt 2008). Previous research has highlighted a plethora of factors influencing voting, ranging between individual-level demographic determinants, such as education, income, occupation and age, and contextual-level conditions, such as characteristics of the voting system and compositional features (for a good review of this research, see Harder and Krosnick 2008). We include as many of these influences as control variables in our analyses (see further below).

ESS respondents are also asked whether or not they have done a specific political action (e.g. contacting politicians, signing petitions, working in political parties, and so on; an exhaustive list can be found on the ESS official website) during the last 12 months. Although such alternative forms of participation are much less common, it is commonly assumed that rising sophistication levels change the nature of participation, from traditional and hierarchical to alternative and more egalitarian forms (Dalton 2008, Zuckin et al. 2006). Increasing attention should also be placed on alternative forms of participation as these may even be more influential than conventional ones in terms of their impact on public policies (APSA Task Force on Inequality and American Democracy 2004). For the sake of brevity, we focus on the three most diffused forms of alternative participation, i.e. working in organizations, signing petitions and boycotting products. The question wording of these items was as follows: "There are different ways of trying to improve things in 
[country] or help prevent things from going wrong. During the last 12 months, have you done any of the following?" (1) "worked in another organization or association" (i.e. not a political party or action group); (2) "signed a petition"; (3) "boycotted certain products".

\subsection{Independent Variables}

Three main independent variables are put under scrutiny, i.e. income at the individual level, income inequality and a measure of the economic crisis at the macro-level. Since we are firstly interested in the role of economic resources at the individual level, we focus on the role of the household's total net income. Some economists prefer consumption expenditures instead, since it is more smoothed over time and less volatile than income. However, as Brandolini and Smeeding (2011) discuss in more details, consumption is preferred in less developed countries, whereas income remains the prevalent indicator within rich countries, as it represents the possibility to consume and, as measured over a span of a year, a satisfactory measure of material standards of living. The first difficulty we had to face was the harmonization of the two income scales provided by the first three rounds and the last three rounds of the ESS, i.e. the 12-point fixed scale provided by ESS 1, 2 and 3, and the 10-point country-specific scale provided from ESS 4 on. In order to create a comparable measure for all rounds, we first identified the category with the median income earner for each country; then, we recoded all respondents with income above the median with 1 , and the rest with 0 . Though providing a rough measure of within-country distribution of income, the dummy variable allows us to evaluate the impact of earning an income above the median on the propensity to participate.

At the country-year level, we take the Gini index of income inequality as our measure of economic inequality. Country- and year-specific values are obtained from the Standardized World Income Inequality Database (SWIID) created by Solt (2016), which is the largest database available in this respect.

Measuring the economic crisis is less straightforward, given its multidimensional nature and the many components that one may associate to it. Whereas aforementioned studies address the effects of each dimension separately, we developed a synthetic measure of the Recession following Kriesi (2014). This measure, which we labeled "Economic Crisis Index" (ECI), is based on the GDP growth rate in the year preceding the ESS fieldwork, the budget deficit/surplus in the year before the survey, and the unemployment rate of the same year. Similar to the Gini index it has countryand year-specific values. High values denote negative GDP growth, large budget deficits and high unemployment and thus reflect a severe economic crisis. ${ }^{\text {iii }}$ 
Further control variables are included in the models. First of all, we control for levels of economic prosperity (measured by GDP per capita), which is included as a county-year variable. Several studies confirm that turnout tends to be higher in economically advanced societies (Blais and Dobrzynska 1998; Norris 2002; Fornos, et al. 2004). However, this pattern is confirmed only in studies including rich and poor countries, whereas it does not hold in analyses based on countries with less variation in affluence, such as Western democracies (Blais 2007). Secondly, postcommunist legacy is also taken as a potentially influential factor. The literature shows that participation is systematically lower in post-communist countries (Howard 2003; Bernhard and Karakoc 2007; Pacek et al. 2009). We therefore create a dummy variable that distinguishes postcommunist countries from others.

Several covariates are controlled for also at the individual level. The role of education in connection to political participation has been assessed since long by the literature (e.g. Almond and Verba, 1963) and its relevance is confirmed over and over (Wolfinger and Rosenstone 1980; Verba et al. 1995; Blais 2000). For reasons of parsimony, we regroup the existing categories provided by ESS into three different groups, i.e. those with 10 years of education or lower recoded as 1 , those with 11 to 13 years of education recoded as 2, those with more than 14 years of education recoded as 3 . By doing so, we create three categories that include approximately $33 \%$ of the population each. Classically, we expect education to have a positive influence on individual propensity to participate.

Age is the second most significant factor according to some studies (Blais 2000; 2007), although its impact may be multifaceted. Whereas younger generations are generally supposed to be less interested in political engagement, recent studies suggest that they tend to vote less, but participate more through alternative channels, e.g. protest actions (Melo and Stockemer 2014). Similarly, gender is expected to matter as well, since existing studies find marked differences between males and females in intended political participation (e.g. Hooghe and Stolle 2004). A dummy variable on the place of birth is included, as being born in another country most likely depresses interest and engagement in the political process (cf. Diehl and Blohm 2001).

\section{Empirical analysis}

\subsection{The impact of economic inequality}

As previously mentioned, we work on a hierarchically structured dataset, with individuals (level-1) clustered in country-years (level-2), which are in turn clustered in countries (level-3). We also 
expect political engagement to be shaped both by predictors at the individual level and at the country-year level and by interactions between these variables. We therefore estimate a series of Multilevel Models (MIM). MLM is appropriate when data are nested, whereas using OLS regression on nested data - by means of disaggregating level-2 variables at level-1 - would overestimate the effect of macro-level factors (Snijders and Bosker 1999, Hox 2002). We estimate a three-level model (of countries, country-years and individuals) rather than a two level one (of country-years and individuals) to correct for the bias produced by the non-independence of observations concerning years within countries (the same strategy was adopted by Solt in his articles and by a number of studies that rely on repeated observations over time; see also Koster and Kaminska 2011). Since our dependent variables are binary coded, we estimate Binomial Multilevel Models with random effects. The table below reports the coefficients for two models for each form of participation: in the first (Model 1), we test the main effects; in the second (Model 2), we introduce the interactions of Gini and ECI with individual income. As each of these models includes both Gini and ECI, these factors effectively control for one another. ${ }^{\text {iv }}$

\section{(Table 1 about here)}

We start by reporting the main effects of the predictors on the participation outcomes. Model 1 partially confirms findings from previous studies showing the detrimental impact of income inequality on the likelihood to participate. As a rule, inequality decreases the probability to participate - of approximately 3-4 points percentage ${ }^{\mathrm{v}}$ - , even though its effect is significant only at the lowest level of statistical significance.

What about the gap between the rich and poor in countries with different levels of inequality? We address this question by including interaction terms between income inequality and household's net income in the model (Model 2), which is the standard approach in studies interested in the contingent effect of macro-level variables on individual level resources (e.g. Duch and Sagarzuzu 2014; Anderson 2007; Aguinis and Culpepper 2015). On first impression, the interaction terms are neither always statistically significant, nor do they all go in the same direction. However, their interpretation on the sole basis of their table coefficients is misleading for a number of methodological reasons. Among other things, Brambor and his colleagues explain that it is not possible to infer whether a certain predictor $\mathrm{X}$ has a meaningful conditional effect on $\mathrm{Y}$ from the magnitude and significance of the interaction term with $\mathrm{Z}$. Furthermore, it is perfectly possible for the marginal effect of $\mathrm{X}$ on $\mathrm{Y}$ to be significant for substantively relevant values of the modifying variable $\mathrm{Z}$, even if the coefficient on the interaction term is insignificant (Brambor et al. 2006). 
Because of this we take a closer look at the interactions by plotting the interaction terms. In the plots below we show how the effect of income on participation varies across different levels of inequality. The greater this effect, the larger the gap between the rich and the poor. The plots thus allow us to directly address the statement about the participation gap in Hypothesis 1 . We follow the same strategy for assessing the interaction between economic crisis and income (see Figures 5-8 further down), thus allowing us to engage with Hypothesis 3.

(Figures 1-4 about here)

As the Figure 1 shows, the effect of income barely changes under different levels of economic inequality in the case of voting. If anything, the Gini index contributes to enlarge the participatory gap between rich and poor (i.e. the slope is slightly positive), but the effect is not significant and too weak to be taken into account. Nevertheless, the other graphs tell a radically different story: on the one hand, our expectation $\underline{s}$ are not confirmed by the second interaction, as the divide between the rich and the poor significantly decreases alongside rising inequality in the case of working in organizations. On the other hand, the disparity-exacerbating effect of inequality is confirmed by the other two forms of participation: income inequality widens the gap between the rich and the poor for boycotting products and signing a petition. In case of the latter, income does not make a difference in the most equal countries but becomes a positive predictor of signing a petition as inequality increases. All in all, Solt's findings and our first working hypothesis $\left(\mathrm{H}_{1}\right)$ are partially confirmed: economic inequality tends to depress overall levels of participation and enhances the gap between the rich and the poor on some alternative forms of political participation.

\subsection{The impact of the economic crisis}

The two models address the second issue of the article as well, i.e. testing the main and conditional effect of the economic crisis. Following Kern et al. (2015), we control this effect for a number of factors, including the main and contingent effects of income inequality. As compared to the previous section, one thing seems clear: the economic crisis does not appear to have much of an effect on overall participation as its effect is not significant in three out of four cases (see Model 1). Rather than fueling or depressing citizens' engagement, the economic crisis seems to have no consequences at all at first sight, with the notable exception of voting which is significantly reduced by economic downturn. This disconfirms Hypothesis 2 which expected the economic crisis to enhance participation. 
A more careful evaluation is needed concerning the interaction terms in Model 2 and in the light of the aforementioned clarification by Brambor and colleagues (2006). Similar to the previous section, we plot the interaction terms in order to evaluate whether the effect of income varies under different economic performances.

(Figures 5 - 8)

Again, the act of voting seems to be the most immune to contextual influences: the participatory gap determined by household income remains stable, no matter if measured in countries hit by the crisis (on the right of the figure) or in countries with high-performing economies. On the contrary, the same analysis on other forms of participation highlights more variation: once controlled for all other economic factors, the effect of income on the propensity to be part of an organization drops as the economic crisis becomes more severe. Even more interestingly, the effect of income on the propensity of boycotting products is apparently not significant when the economy fares well - or barely significant in the case of signing petitions. In both cases, the effect becomes more evidently significant and negative under poor performances. This means that the worse-off are comparatively more active than the rich when the crisis hits hard, which is coherent with expectations based on the grievance theory discussed above.

\subsection{The impact of the control variables}

In terms of the control variables, economic prosperity, the other variable measured at the yearcountry level, has little influence on participation, which is consistent with Blais' argument (2007) that no significant difference exists among countries with relatively little variation in affluence. If anything, economic wellbeing reduces traditional voting but encourages membership in organizations. A very different story is reported by the dummy on post-communist countries, as the analysis confirms the previous findings on the persistent divide between Eastern and Western European countries in individual propensity to engage politically (Howard 2003, Bernhard and Karakoc 2007, Pacek et al, 2009). In general, Western Europeans are approximately 4 to 5 percentage points more likely to be active than Eastern Europeans in all forms of participation under scrutiny.

Interesting findings emerge among control variables at the individual level too. Unsurprisingly, being born in another country heavily decreases the likelihood to be politically active. Besides the strong effect registered for education ${ }^{\mathrm{vi}}$, the most interesting insights pertain the 
role of gender and age. More specifically, the analysis sheds light on the different propensities to participate of males and females: whereas males significantly vote more and work more in organizations, females are more active both in the case of boycotting products and signing petitions, even though the difference in both cases is around 1 point percentage. Similarly, the role of age needs some refinement, as suggested by recent studies (e.g. Melo and Stockemer 2014). Younger generations work less in associations; however, they are significantly more active in signing petitions (up to two points percentage, if we compare respondents in their 20s and respondents in their 70s). Finally, the role of economic resources at the individual level is confirmed for all forms of participation. The coefficients in Model 1 show that belonging to the part of the population that earns an income above the median change the probability to be active, but it accounts for an average difference estimated between 1 and 2 points percentage in the three forms of participation under scrutiny. This confirms that other predictors at the individual level are more important in determining the likelihood of political engagement, first and foremost education, given the gap of approximately 5 percentage points between the most and the least educated for all forms of participation.

\section{Summary and discussion}

To say it with Lijphart (1997), if democracy is at its core associated with the ideal of political equality, how does it cope with a reality of unequal participation which, in turn, is likely to lead to an unequal influence over the outcome of the democratic decision-making process? To be sure, the concept of political equality is complicated and discussing it is well beyond the scope of this article. Measuring political inequality entails different and complementary strategies, broadly distinguished between those that focus on the input side and those focusing on the output side (Dubrow 2014). In other words, inequality can be assessed either in terms of unequal political input of certain groups in the decision-making process, or in terms of the differential effects of political decisions on different social groups. Focusing on citizens' participation clearly belongs to the former strategy and it moves from the idea that even if the choice of non-participation at the individual level is perfectly compatible with the framework of liberal democracy, recurring statistical patterns raise an issue of underrepresentation of certain groups' interests. As Offe puts it, the problem arises when patterns of uneven under-utilization of political resources exist: "here non-participation is evidently not freely chosen, or it is freely chosen as the conditions that are statistically correlated with this choice are themselves not freely chosen, but conditional on circumstances that are beyond the control of those 
affected by them" $(2013,203)$. In view of this observation, the current article examined whether within-country distribution of participation varies under different macro-economic circumstances.

Our analysis offers a twofold contribution to the literature. On the one hand, it tests existing findings on the impact of economic disparities. More specifically, Solt's comprehensive studies on the role of income inequality $(2008,2010,2015)$ are replicated on European data and his findings are by and large confirmed, even if tested in times of economic turmoil. Income inequality generally reduces overall participation - though its effect is not statistically significant on all forms of participation - and, most importantly, increases the gap between better- and worse-off in three forms of participation out of four (minimally for voting and significantly for signing petitions and boycotting products). Interestingly enough, inequality mitigates the income gap in the case of working in organizations. This is because inequality has depressed overall levels of this form of participation to such an extent that there is relatively little variation in this outcome in the most unequal countries, and apparently too little for income to have an effect. ${ }^{\text {vii }}$ Why there is so little variation in working in organizations in more unequal countries is a question for further research.

On the other hand, the analysis shows that the crisis has no major effect on the propensity to engage, but it does influence the within-country distribution of active citizens. In the case of voting and working in organizations, the income-based divide is mitigated by the crisis; in the case of boycotting products and signing petitions the worse-off are relatively more active than the rich in countries having suffered most from the crisis.

These findings have some theoretical implications as well. Whereas the relative power theory confirms its predictive capability concerning the effects of economic disparities, the grievance model has good explanatory power regarding the effect of economic crises on the political participation of different income groups. This is particularly true for alternative forms of participation. Findings by Kern et al. (2015) are thus confirmed, even if controlled for all factors that were not included in the previous studies. Similar to their study, our results suggest that both theoretical approaches presented in this article (i.e. the relative power theory and the grievance theory) can help to assess participatory tendencies, especially if these are tested in times of economic turmoil.

Why do income inequality and the economic crisis have such contrasting effects on the link between income and political participation and thereby confirm such conflicting theories? We can only speculate about the reasons here. Possibly the diverging effects have to do with the different pace at which the two macro-economic processes operate. While inequality is changing slowly and is taking decades to become notably larger or smaller, an economic crisis can occur suddenly and upset seemingly healthy growth trajectories (as happened in Greece). Perhaps the relative inertia of 
inequality gives rise to a sentiment that not much can be done about it, which in turn might fuel political disengagement and alienation amongst the poor. In contrast, the immediacy of an economic crisis and the acute sense of loss experienced by those most affected by it might incite people to act in an effort to regain what was lost (as illustrated by the mass demonstrations in Greece in the aftermath of the crisis). In other words, while inequality might undermine a sense of external political efficacy, economic crises could well enhance it. This is a question for future research to explore. 
Table 1 - The determinants of political participation (coefficients from multilevel binomial regressions)

\begin{tabular}{|c|c|c|c|c|c|c|c|c|}
\hline & \multicolumn{2}{|l|}{ Vote } & \multicolumn{2}{|c|}{ Working in org } & \multicolumn{2}{|l|}{ Boycott } & \multicolumn{2}{|c|}{ Sign petition } \\
\hline & Model 1 & Model 2 & Model 1 & Model 2 & Model 1 & Model 2 & Model 1 & Model 2 \\
\hline Income & $.037^{* * *}$ & $.035^{* * *}$ & $.021^{* * * *}$ & $.048^{* * * *}$ & $.011^{* * *}$ & -.015 & $.005^{* * *}$ & -.026 \\
\hline & $(.002)$ & $(.012)$ & $(.001)$ & $(.010)$ & $(.001)$ & $(.011)$ & $(.001)$ & $(.012)$ \\
\hline Gini & $-.004^{*}$ & $-.004^{*}$ & $-.005^{*}$ & $-.004^{*}$ & -.003 & $-.004^{*}$ & $-.006^{*}$ & $-.006^{*}$ \\
\hline & $(.002)$ & $(.002)$ & $(.002)$ & $(.002)$ & $(.002)$ & $(.002)$ & $(.003)$ & $(.003)$ \\
\hline ECI & $-.001^{* *}$ & $-.001^{* *}$ & .000 & .000 & -.000 & -.0003 & -.0005 & -.0004 \\
\hline & $(.000)$ & $(.000)$ & $(.000)$ & $(.000)$ & $(.000)$ & $(.0003)$ & $(.0004)$ & $(.0004)$ \\
\hline Gini*income & & .0001 & & $-.001^{* *}$ & & $.001^{* *}$ & & $.001^{* *}$ \\
\hline & & $(.000)$ & & $(.000)$ & & $(.000)$ & & $(.000)$ \\
\hline ECI*income & & -.000 & & $-.0002^{*}$ & & $-.0005^{* * *}$ & & -.0002 \\
\hline & & $(.002)$ & & $(.0001)$ & & $(.0001)$ & & $(.0001)$ \\
\hline Individual con & rols & & & & & & & \\
\hline $\begin{array}{l}\text { Most } \\
\text { educated }\end{array}$ & $\begin{array}{l}.151^{* * *} \\
(.002)\end{array}$ & $\begin{array}{l}.151^{* * * *} \\
(.002)\end{array}$ & $\begin{array}{l}.111^{* * *} \\
(.002)\end{array}$ & $\begin{array}{l}.111^{* * *} \\
(.002)\end{array}$ & $\begin{array}{l}.141^{* * * *} \\
(.002)\end{array}$ & $\begin{array}{l}.141^{* * * *} \\
(.002)\end{array}$ & $\begin{array}{l}.159^{* * *} \\
(.002)\end{array}$ & $\begin{array}{l}.159^{* * *} \\
(.002)\end{array}$ \\
\hline $\begin{array}{l}\text { Medium } \\
\text { educated }\end{array}$ & $\begin{array}{l}.069^{* * *} \\
(.002)\end{array}$ & $\begin{array}{l}.069^{* * *} \\
(.002)\end{array}$ & $\begin{array}{l}.038^{* * *} \\
(.002)\end{array}$ & $\begin{array}{l}.038^{* * *} \\
(.002)\end{array}$ & $\begin{array}{l}.048^{* * *} \\
(.002)\end{array}$ & $\begin{array}{l}.048^{* * * *} \\
(.002)\end{array}$ & $\begin{array}{l}.061^{* * *} \\
(.002)\end{array}$ & $\begin{array}{l}.060^{* * *} \\
(.002)\end{array}$ \\
\hline $\begin{array}{l}\text { Gender } \\
\text { (female) }\end{array}$ & $\begin{array}{l}-.007^{* * *} \\
(.002)\end{array}$ & $\begin{array}{l}-.007^{*} \\
(.002)\end{array}$ & $\begin{array}{l}-.040^{* * *} \\
(.001)\end{array}$ & $\begin{array}{l}-.040^{* * *} \\
(.001)\end{array}$ & $\begin{array}{l}.014^{* * *} \\
(.001)\end{array}$ & $\begin{array}{l}.014^{* * *} \\
(.001)\end{array}$ & $\begin{array}{l}.021^{* * *} \\
(.002)\end{array}$ & $\begin{array}{l}.021^{* * *} \\
(.002)\end{array}$ \\
\hline Age & $\begin{array}{l}.005^{* * *} \\
(.000)\end{array}$ & $\begin{array}{l}.005^{* * *} \\
(.000)\end{array}$ & $\begin{array}{l}.001^{* * *} \\
(.000)\end{array}$ & $\begin{array}{l}.001^{* * *} \\
(.000)\end{array}$ & $\begin{array}{l}.000 \\
(.000)\end{array}$ & $\begin{array}{l}.000 \\
(.000)\end{array}$ & $\begin{array}{l}-.001^{* * *} \\
(.000)\end{array}$ & $\begin{array}{l}-.001^{* * *} \\
(.000)\end{array}$ \\
\hline $\begin{array}{l}\text { Born in } \\
\text { another } \\
\text { country }\end{array}$ & $\begin{array}{l}-.183^{* * *} \\
(.003)\end{array}$ & $\begin{array}{l}-.183^{* * *} \\
(.003)\end{array}$ & $\begin{array}{l}-.049^{* * *} \\
(.002)\end{array}$ & $\begin{array}{l}-.049^{* * *} \\
(.002)\end{array}$ & $\begin{array}{l}-.033^{* * *} \\
(.003)\end{array}$ & $\begin{array}{l}-.033^{* * *} \\
(.003)\end{array}$ & $\begin{array}{l}-.071^{* * *} \\
(.003)\end{array}$ & $\begin{array}{l}-.071^{* * *} \\
(.003)\end{array}$ \\
\hline $\begin{array}{l}\text { Country-year } \\
\text { controls }\end{array}$ & & & & & & & & \\
\hline $\begin{array}{l}\text { GDP } \\
\text { capita }\end{array}$ & $\begin{array}{l}-.0005^{*} \\
(.0002)\end{array}$ & $\begin{array}{l}-.0005^{*} \\
(.0002)\end{array}$ & $\begin{array}{l}.001^{* *} \\
(.000)\end{array}$ & $\begin{array}{l}.001^{* *} \\
(.000)\end{array}$ & $\begin{array}{l}.0004 \\
(.0003)\end{array}$ & $\begin{array}{l}.0004 \\
(.0003)\end{array}$ & $\begin{array}{l}-.0003 \\
(.0003)\end{array}$ & $\begin{array}{l}-.0003 \\
(.0003)\end{array}$ \\
\hline Country contre & & & & & & & & \\
\hline $\begin{array}{l}\text { Post- } \\
\text { communism }\end{array}$ & $\begin{array}{l}-.129^{* * *} \\
(.026)\end{array}$ & $\begin{array}{l}-.129^{* * *} \\
(.026)\end{array}$ & $\begin{array}{l}-.106^{* * *} \\
(.029)\end{array}$ & $\begin{array}{l}-.106^{* * *} \\
(.029)\end{array}$ & $\begin{array}{l}-.108^{*} \\
(.031)\end{array}$ & $\begin{array}{l}-.108^{*} \\
(.031)\end{array}$ & $\begin{array}{l}-.150^{* *} \\
(.039)\end{array}$ & $\begin{array}{l}-.150^{* *} \\
(.039)\end{array}$ \\
\hline Intercept & $\begin{array}{l}.604^{* * *} \\
(.062)\end{array}$ & $\begin{array}{l}.605^{* * *} \\
(.063)\end{array}$ & $\begin{array}{l}.207^{* * *} \\
(.062)\end{array}$ & $\begin{array}{l}.193^{* *} \\
(.062)\end{array}$ & $\begin{array}{l}.182^{* *} \\
(.065)\end{array}$ & $\begin{array}{l}.196^{* *} \\
(.065)\end{array}$ & $\begin{array}{l}.392^{* * *} \\
(.078)\end{array}$ & $\begin{array}{l}.409^{* * *} \\
(.078)\end{array}$ \\
\hline Variance comp & onents & & & & & & & \\
\hline Residuals & .391 & .391 & .335 & .335 & .348 & .348 & .393 & .393 \\
\hline $\begin{array}{l}\text { Country- } \\
\text { year }\end{array}$ & .059 & .059 & .067 & .067 & .071 & .071 & .092 & .092 \\
\hline Countries & .028 & .028 & .026 & .026 & .027 & .027 & .032 & .032 \\
\hline N level-1 & 248,741 & 248,741 & 248,741 & 248,741 & 248,741 & 248,741 & 248,741 & 248,741 \\
\hline N level-2 & 130 & 130 & 130 & 130 & 130 & 130 & 130 & 130 \\
\hline N level-3 & 29 & 29 & 29 & 29 & 29 & 29 & 29 & 29 \\
\hline AIC & 217919 & 217767 & 160040 & 160062 & 178910 & 178928 & 238959 & 238985 \\
\hline
\end{tabular}


Figure 1 - Marginal effect of income on voting conditional on the level of income inequality

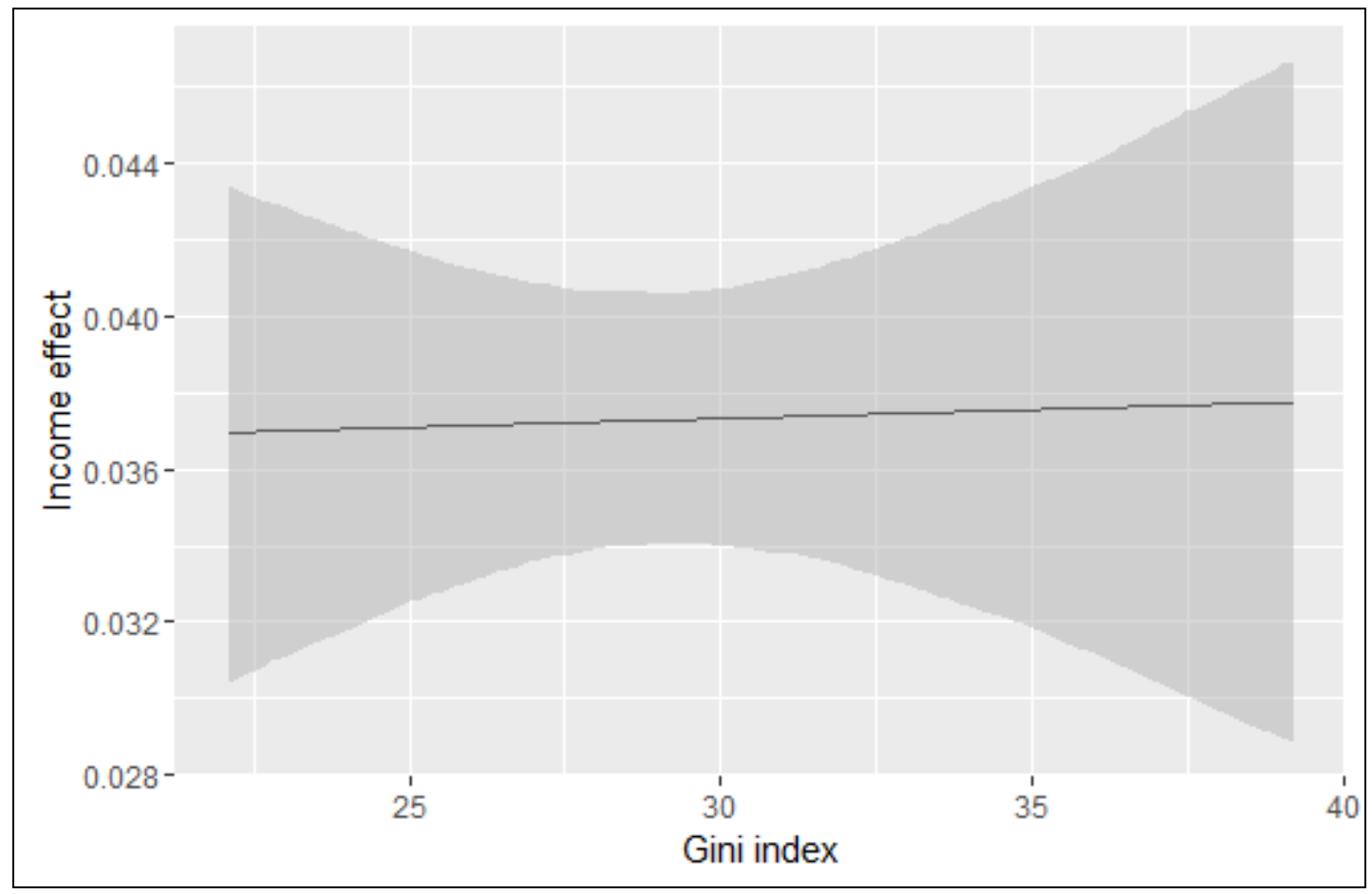

Figure 2 - Marginal effect of income on working in organizations conditional on the level of income inequality

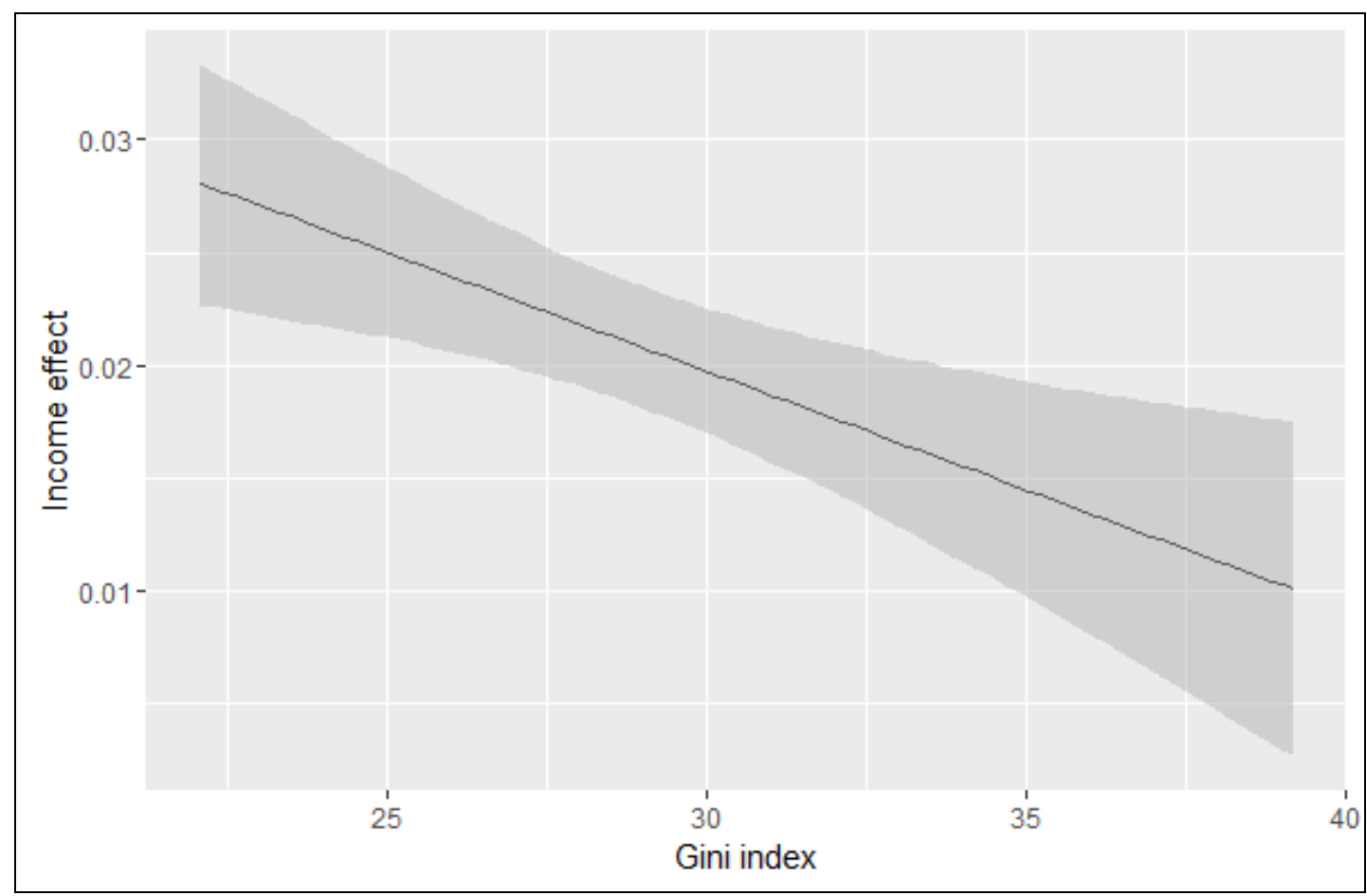


Figure 3 - Marginal effect of income on boycotting products conditional on the level of income inequality

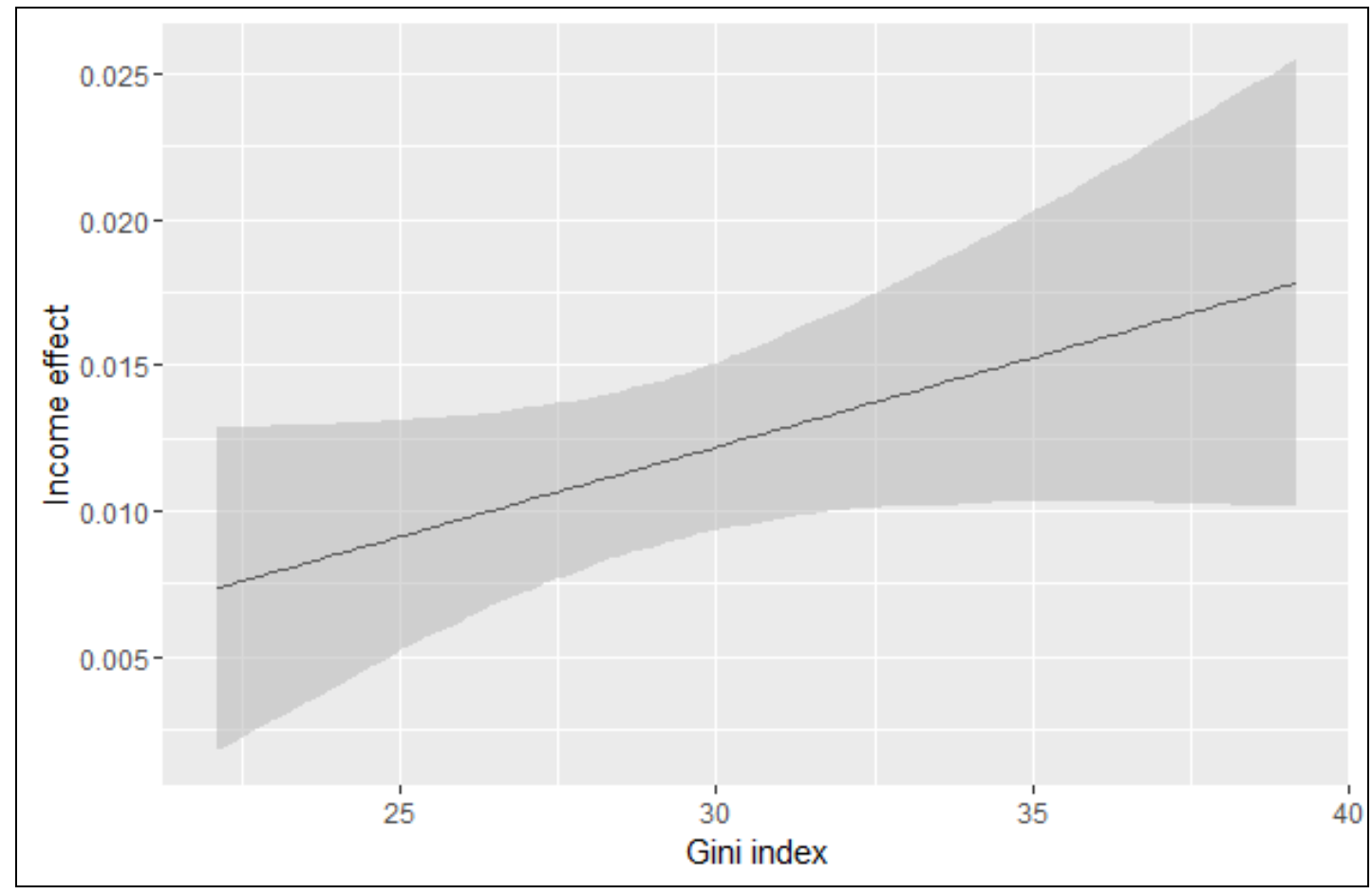

Figure 4 - Marginal effect of income on signing petitions conditional on the level of income inequality

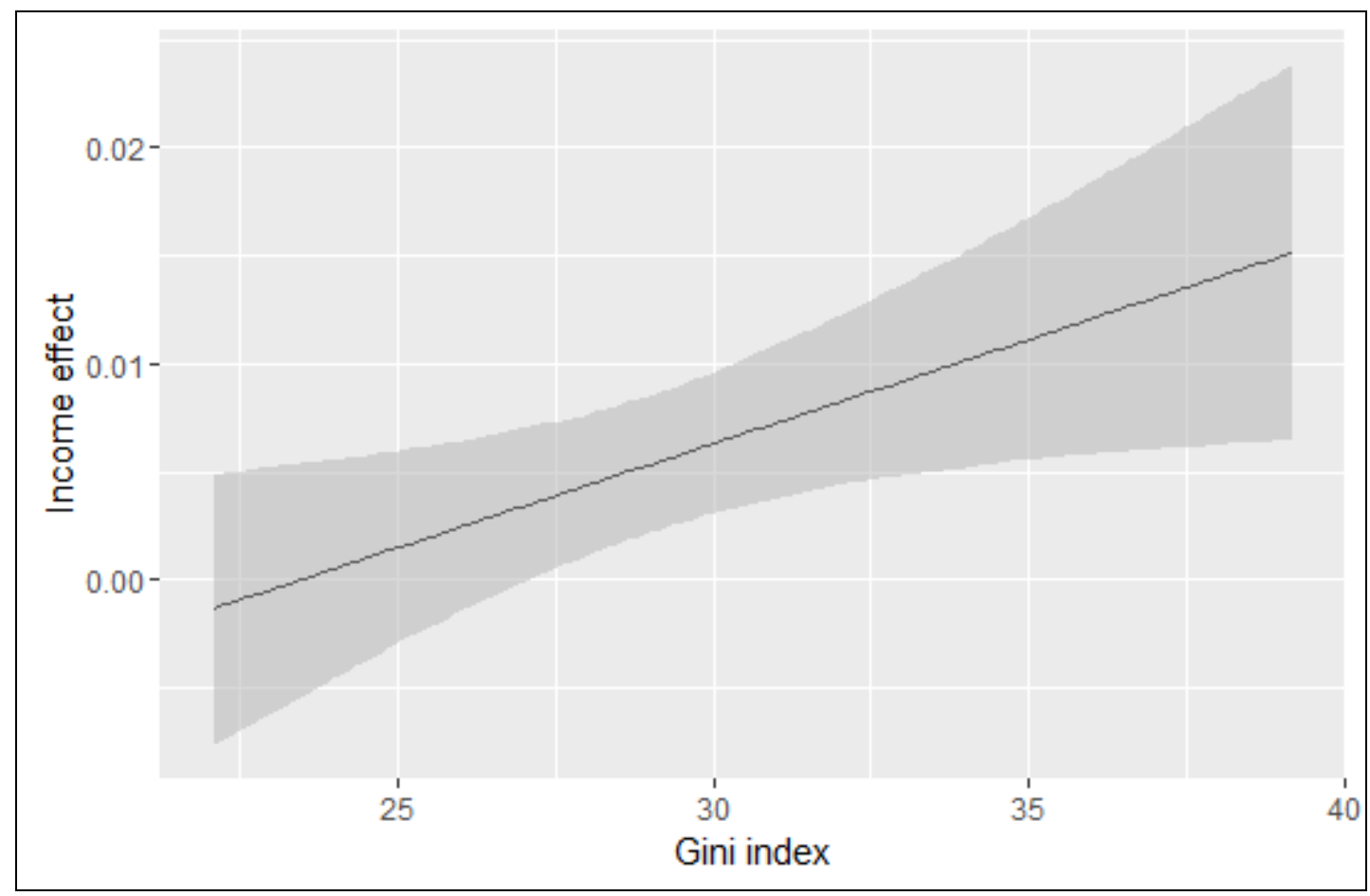


Figure 5 - Marginal effect of income on voting conditional on the economic crisis

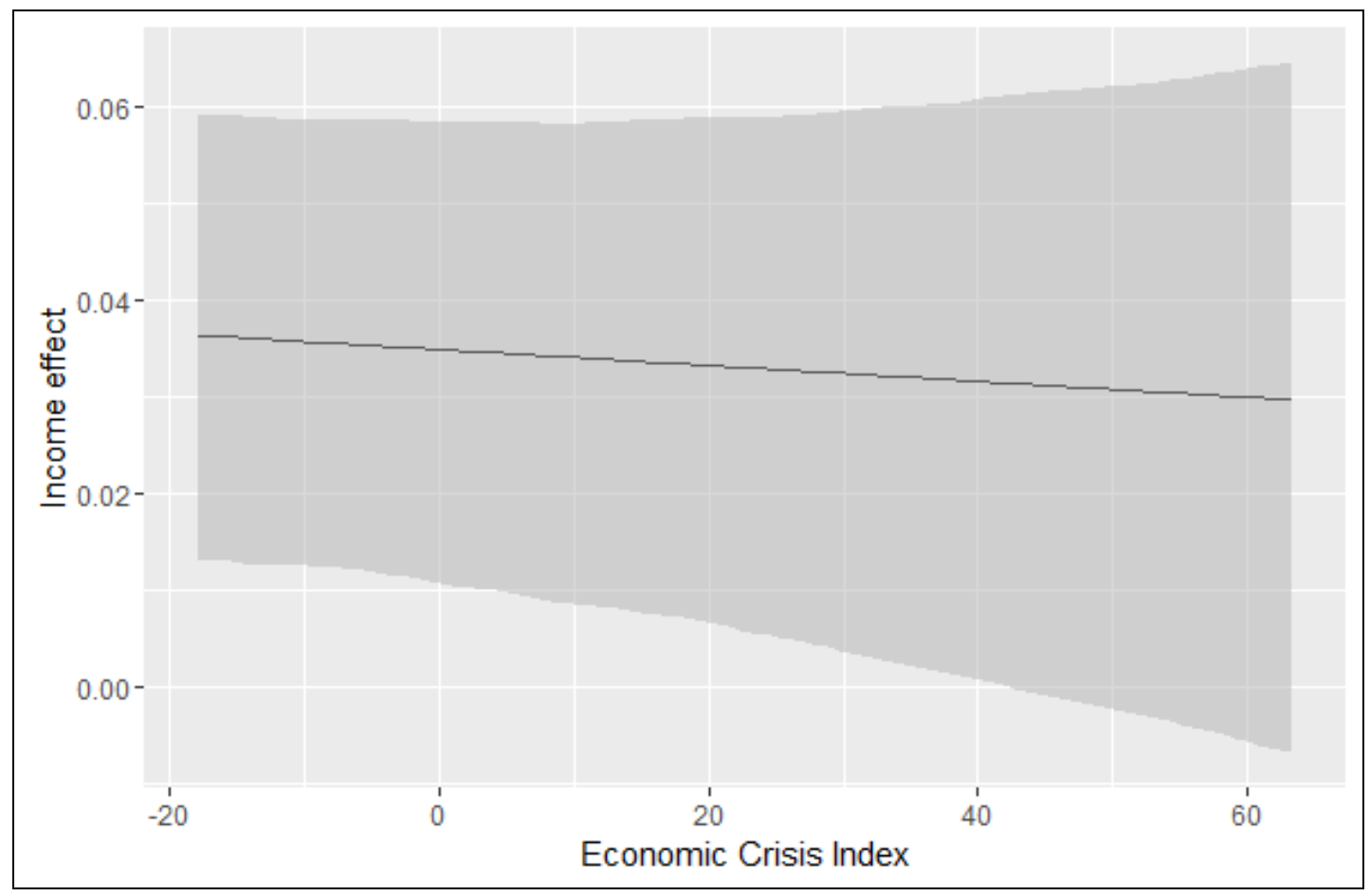

Figure 6 - Marginal effect of income on working in organizations conditional on the economic crisis

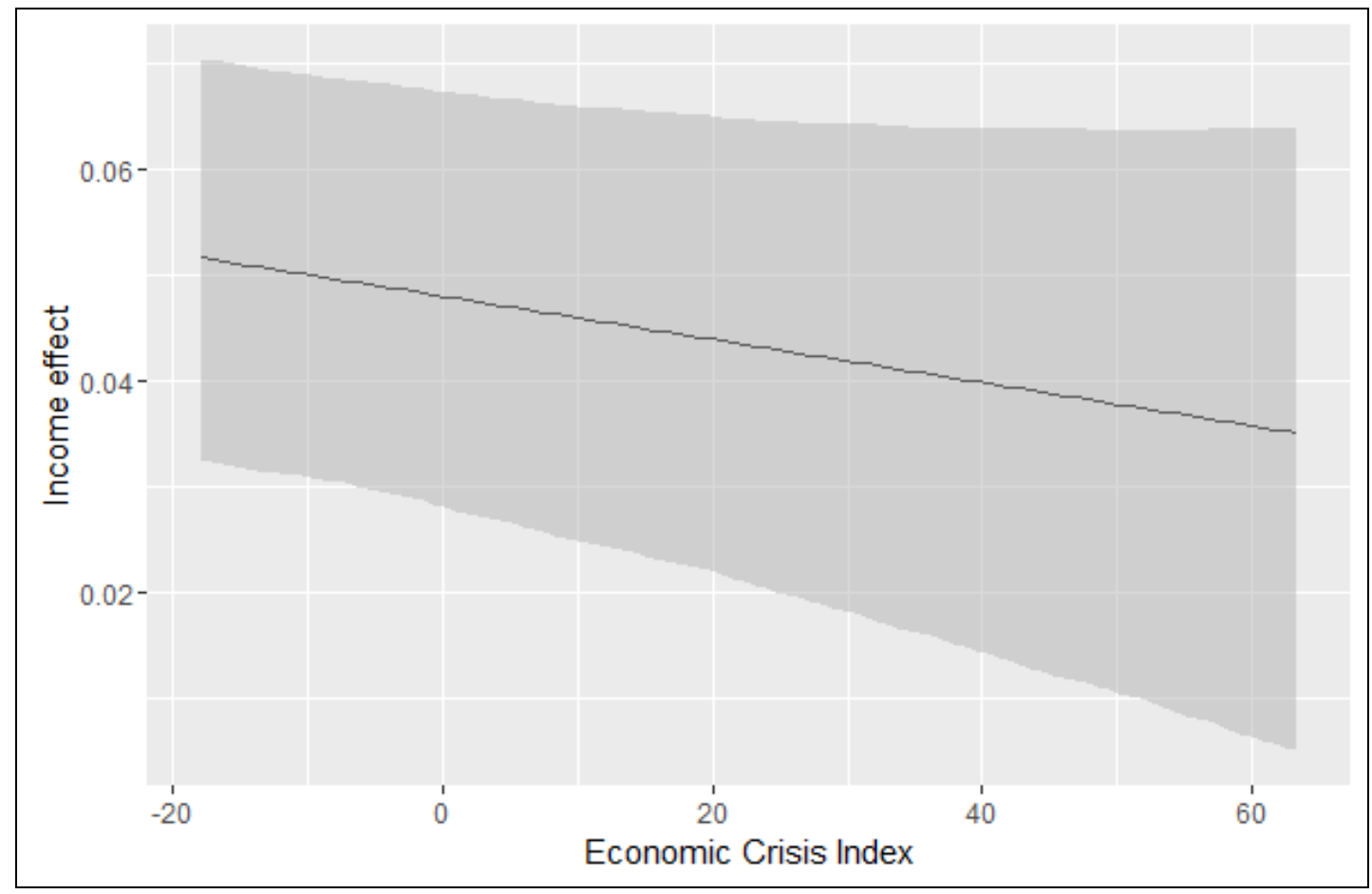


Figure 7 - Marginal effect of income on boycotting products conditional on the economic crisis

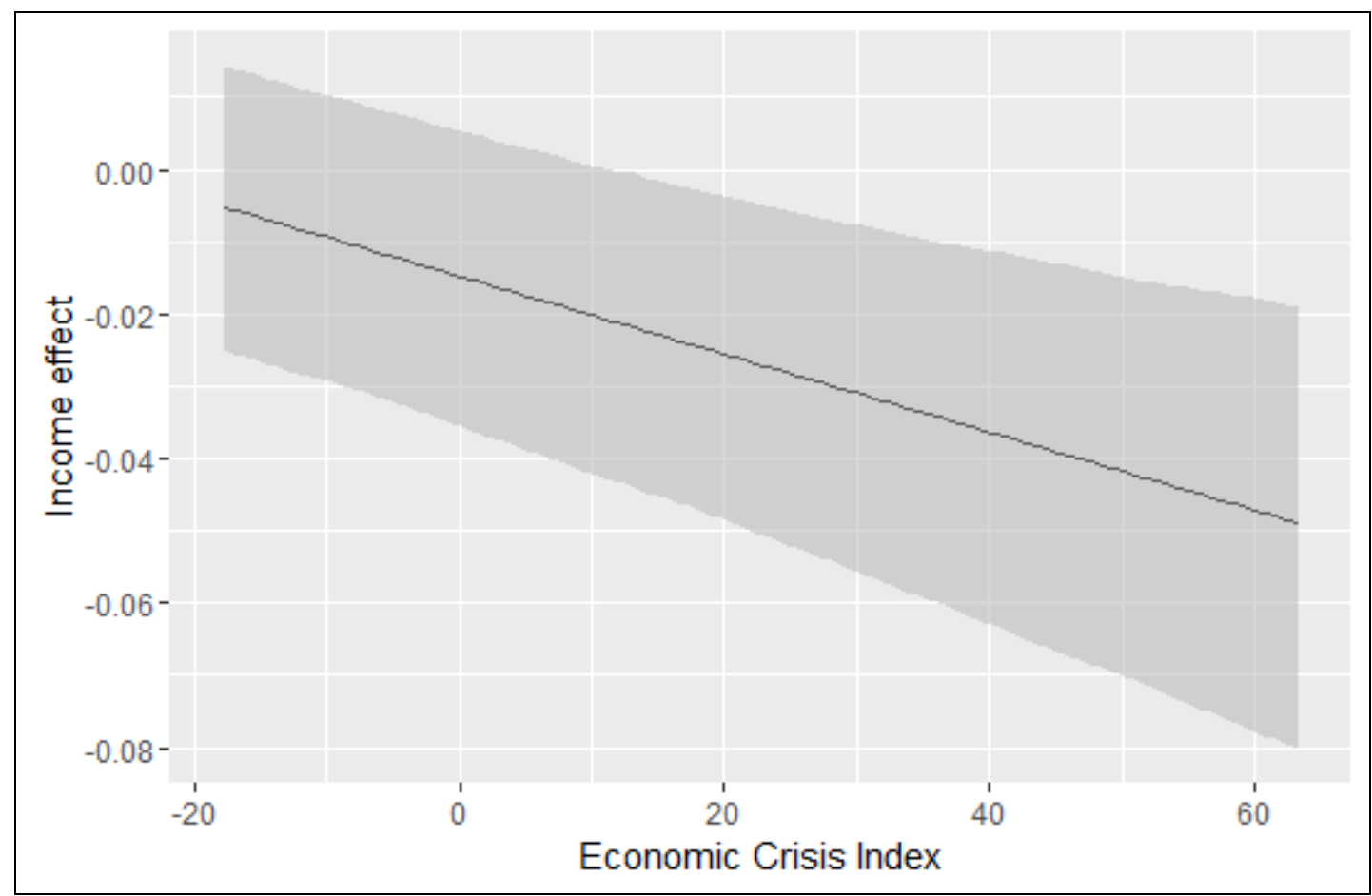

Figure 8 - Marginal effect of income on signing petitions conditional on the economic crisis

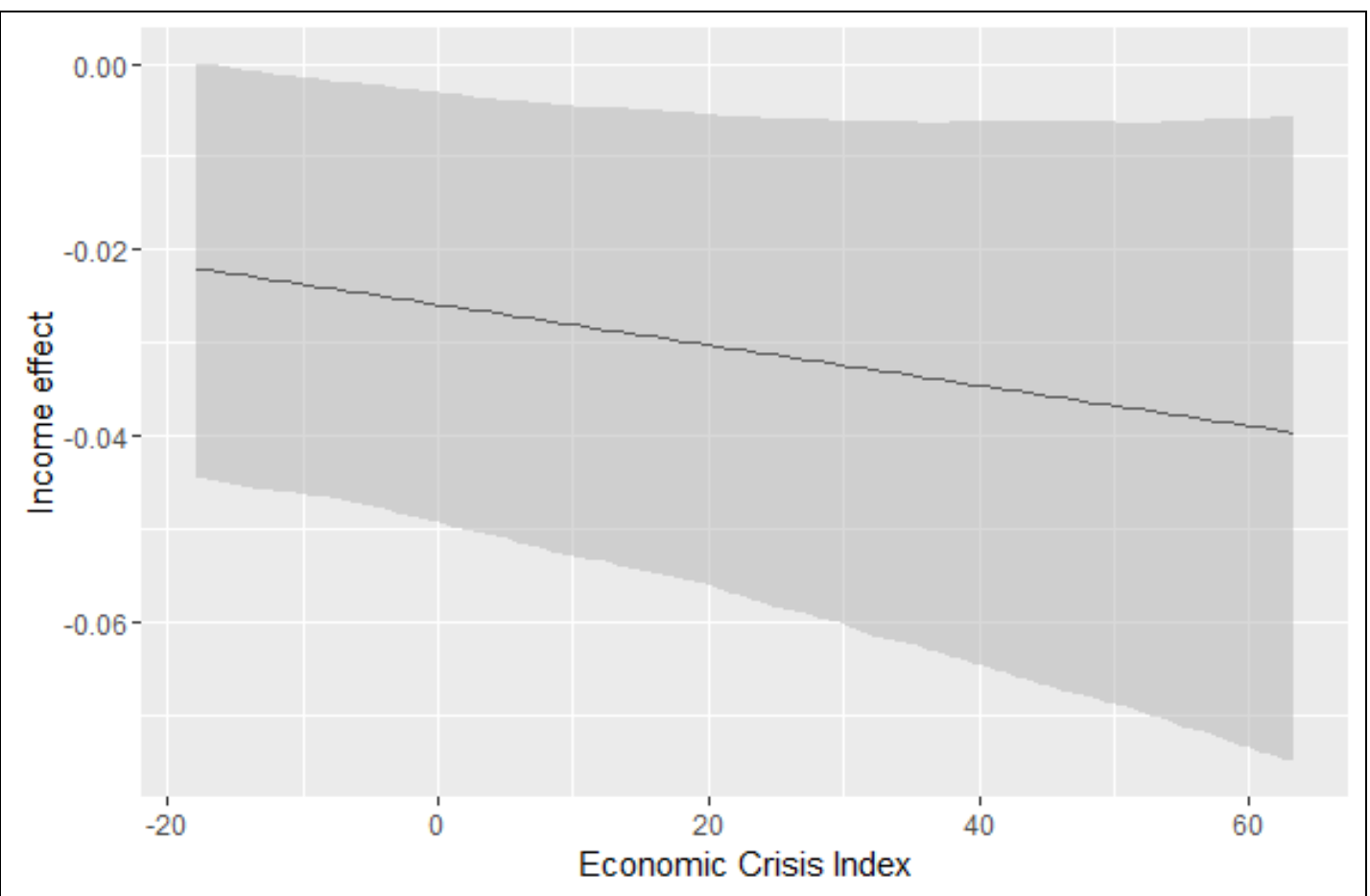


${ }^{\mathrm{i}}$ Taking into consideration only the GDP per capita annual growth (\%) without controlling it for the overall level of wellbeing (e.g. GDP per capita itself) overestimates the economic conditions of some fast developing countries (e.g. Estonia) as compared to rich ones (e.g. (e.g. Finland).

ii Differently from Kern et al. (2015), we exclude those countries that are rated either as not free or partly free by Freedom House, i.e. Albania, Russia, Turkey, Ukraine and Kosovo. The reason for this is that participating to political affairs may acquire a totally different meaning in full democracies and in authoritarian or semi-authoritarian regimes. Furthermore, we must exclude from the analysis all those countries where the ESS question on income is not included (Bulgaria 2008, Estonia 2004 and 2006, Cyprus 2006 and 2008, Hungary 2002 and 2006, France 2002, Ireland 2002, Portugal 2010 and Slovakia 2008).

iii Economic Crisis Index = GDP Growth - Unemployment + Deficit-Surplus. For the sake of clarity, we then reverse the scale, so that higher scores correspond to more severe economic hardship. We created the measure by first standardising the three variables that it includes and then by subtracting gdp growth from the sum of budget deficit and unemployment rate.

iv Although we have not found any theoretical leads in the literature to suggest that austerity might influence whether income inequality enhances or mitigates the participation gap between the rich and poor, we nonetheless checked for this possibility by running a model with a three-way interaction between economic crisis, income inequality and individual income and a two-way interaction between economic crisis and income inequality. The effects of these interactions turned out to be insignificant (results can be obtained from the authors upon request). Hence we only report the results of the more parsimonious models (i.e. Models 1 and 2).

${ }^{\mathrm{v}} \mathrm{We}$ are referring here to the predicted probabilities computed on the basis of the regression coefficients. In Binomial Multilevel Models, the coefficient $\beta$ associated to each $X_{n}$ is the effect of a unit increment of $X$ on the logit scale (i.e. log-odds, or the natural logarithm of the odds determining the probability of a certain outcome $\mathrm{Y}$ associated to $\mathrm{X}$ ). The probabilities are computed by assigning different scores for the variable under scrutiny, holding all other variables constant at their mean value and dummy variables at 1 (for more on predicted probabilities, please see Afshartous and de Leeuw 2005; Skrondal and Rabe-Hesketh 2009).

vi Three meaningful categories are built on the basis of the years of full-time education completed in order to include approximately $30 \%$ of the respondents in each.

${ }^{\text {vii }}$ A table showing the variation in the four outcomes across different levels of inequality and economic crisis can be obtained from the authors upon request. 


\section{References}

- Aguinis, H., Gottfredson, R.K. and Culpepper, S.A. (2013) Best-Practice Recommendations for Estimating Cross-Level Interaction Effects. Journal of Management 39(6): 1490-1528.

- Aguinis, H. and Culpepper, S.A. (2015) An Expanded Decision-Making Procedure for Examining Cross-Level Interaction Effects with Multilevel Modeling. Organizational Research Methods. Published online: DOI: 10.1177/1094428114563618.

- Almond, G.A. and Verba, S. (1963) The civic culture: Political attitudes and democracy in Five Nations. Boston: Little, Brown \& Co.

- Anderson, C.J. (2007) The Interaction of Structures and Voter Behavior. In: R.J. Dalton and H.-D. Klingemann (eds.) The Oxford Handbook of Political Behavior. New York: Oxford University Press, pp. 589-609.

- Anderson, C.J. and Beramendi, P. (2008) Income, Inequality, and Electoral Participation. In P. Beramendi and C.J. Anderson (eds.) Democracy, Inequality, and Representation in Comparative Perspective. New York: Russell Sage Foundation, 258-311.

- Ansolabehere, S., Figueiredo, de J. and Snyder, J. M. (2003) Why Is There So Little Money in U.S. Politics? Journal of Economic Perspectives 17(1): 105-30.

- APSA Task Force on Inequality and American Democracy (2004) American Democracy in an Age of Rising Inequality. Perspectives on Politics 2(4): 651-670.

- Afshartous, D. and de Leeuw, J. (2005) Prediction in multilevel models. Journal of Educational and Behavioral Statistics 30(1): 109-139.

- Bachrach, P. and Baratz, M.S. (1970) Power and Poverty: Theory and Practice. London: Oxford University Press.

- Baldacci, E., de Mello, L. and Inchauste, G. (2002) Financial Crises, Poverty and Income Distribution. Finance and Development 39(2): 24-27.

- Bermeo, N. (2012) Does Electoral Democracy Boost Economic Equality. In: F. Fukuyama, L. Diamond and M.F. Plattner (eds.) Poverty, Inequality, and Democracy. Baltimore: Johns Hopkins University Press, pp. 14-28.

- Bernhard, M. and Karakoç, E. (2007) Civil Society and the Legacies of Dictatorship. World Politics 59(4): 539-567.

- Blais, A. (2000) To Vote or not to Vote? The Merits and Limits of Rational Choice. Pittsburgh: University of Pittsburgh Press.

- Blais A. (2007) Turnout in Elections. In: Dalton, R.J. and Klingemann, H.-D. (eds.) The Oxford Handbook of Political Behavior. Oxford: Oxford University Press, pp. 621-635. 
- Blais, A. and Dobrzynska, A. (1998) Turnout in Electoral Democracies. European Journal of Political Research 33: 239-261.

- Brambor, T., Clar, W.R., and Golder, M. (2006) Understanding Interaction Models: Improving Empirical Analyses. Political Analysis 14(1): 63-82.

- Brandolini, A., and Smeeding, T. M. (2011) Income Inequality in Richer and OECD Countries. In: B. Nolan, W. Salverda and T.M. Smeeding (eds.) The Oxford Handbook of Economic Inequality. Oxford: Oxford University Press, pp. 71-100.

- Dalton, R.J. (2008) Citizen Politics: Public Opinion and Political Parties in Advanced Industrial Democracies, 5th Edition. Washington D.C.: CQ Press.

- Diehl, C. and Blohm, M. (2001). Apathy, Adaptation or Ethnic Mobilization: On the political attitudes of an excluded group, Journal of Ethnic and Migration Studies, 27 (3), 401-20.

- Dubrow, J.K. (2014) Political Inequality in an Age of Democracy: Cross-national Perspectives. London: Routledge.

- Dubrow, J.K., Slomczynski, K.M. and Tomescu-Dubrow, I. (2008) Effects of Democracy and Inequality on Soft Political-Protest in Europe: Exploring the European Social Survey Data.

- Duch, R.M. and Sagarzazu, I. (2014) Crisis Perceptions and Economic Voting Among the Rich and the Poor. In: N. Bermeo and L.M. Bartels (eds.) Mass Politics in Tough Times. New York: Oxford University Press, pp. 224-265.

- Fornos, C.A., Power, T. J. and Garand, J. C. (2004) Explaining Voter Turnout in Latin America: 1980-2000. Comparative Political Studies 37 (8): 909-940.

- Foster, M., and Matheson, K. (1995) Double Relative Deprivation: Combining the Personal and Political. Personality and Social Psychology Bulletin 21: 1167-1177.

- Gaventa, J. (1980) Power and Powerlessness: Quiescence and Rebellion in an Appalachian Valley. Urbana: University of Illinois Press .

- Goodin, R. and Dryzek, J. (1980) Rational Participation: The Politics of Relative Power. British Journal of Political Science 10(3): 273-92.

- Gurr, T.R. (1970). Why Men Rebel. Princeton: Princeton Universtiy Press.

- Harder, J. and Krosnick, J. A. (2008). Why Do People Vote? A Psychological Analysis of the Causes of Voter Turnout. Journal of Social Issues, 64 (3), 525-49.

- Hooghe, M. and Stolle, D. (2004). Good Girls go to the Polling Booth, Bad Boys go Everywhere. Gender Differences in Anticipated Political Participation Among US 14 Year Olds. Women and Politics 26(3-4): 1-23. 
- Howard, M.M. (2003) The weakness of civil society in post-Communist Europe. Cambridge, New York: Cambridge University Press.

- Hox, J. (2002) Multilevel Analysis. Techniques and Application. Malwah, London: Lawrence Erlbaum Associates, Publishers.

- Inglehart, R. and Welzel, C. (2005). Modernization, Cultural Change, and Democracy: The Human Development Sequence. Cambridge: Cambridge UP.

- Karakoç, E. (2013) Economic inequality and its asymmetric effect on civic engagement: evidence from post-communist countries. European Political Science Review 5(2): 197-223.

- Kern, A., Marien, S. and Hooghe, M. (2015) Economic Crisis and Levels of Political Participation in Europe (2002-2010): The Role of Resources and Grievances. West European Politics 38(3): 465-490.

- Klandermans, B., van der Toorn, J. and van Stekelenburg, J. (2008) Embeddedness and Identity: How Immigrants Turn Grievances into Action. American Sociological Review 73(6): 992-1012.

- Koster, F. and Kaminska, M.-E. (2012) Welfare state values in the European Union, 20022008. A multilevel investigation of formal institutions and individual attitudes. Journal of European Public Policy 19(6): 900-920.

- Kriesi, H. (2014) The Political Consequences of the Economic Crisis in Europe: Electoral Punishment and Popular Protest. In: N. Bermeo and L.M. Bartels (eds.) Mass Politics in Tough Times. New York: Oxford University Press, pp. 297-333.

- Lancee, B. and Werfhorst, H.G. van de (2012). Income Inequality and Participation: A Comparison of 24 European Countries. Social Science Research 41: 1166-1178.

- Levinson, M. (2012) No Citizen Left Behind. Cambridge and London: Harvard University Press.

- Lijphart, A. (1997) Unequal Participation: Democracy's Unresolved Dilemma. The American Political Science Review 91(1): 1-14.

- Loose, K. and Jae, D. H. (2011) Explaining Unequal Participation: The Differential Effects of Winter Weather on Voter Turnout. Working Paper 2011-13, Massachusetts Institute of Technology.

- Marsh, A. and Kaase, M. (1979) Background of political action. In Barnes and Kaase (eds.) Political action. Mass participation in five western democracies. Beverly Hills: Sage, pp. 97-136. 
- Melo, D.F. and Stockemer, D. (2014) Age and political participation in Germany, France and the UK: A comparative analysis. Comparative European Politics 12(1): 33-53.

- Morlino, L. (2011) Changes for Democracy. Actors, Structures, Processes. New York: Oxford University Press.

- Norris, P. (2002) Democratic Phoenix: Reinventing Political Activism. Cambridge: Cambridge University Press.

- Offe, C. (2013) Participatory Inequality in the Austerity State: A Supply-Side Approach. In: A. Schäfer and W. Streeck (eds.) Politics in the Age of Austerity. Cambridge: Polity Press, pp. 196-218.

- Pateman, C. (1971) Political Culture, Political Structure and Political Change. British Journal of Political Science 1(3): 291-305.

- Pacek, A.C., Pop-Eleches, G. and Tucker, J.A. (2009) Disenchanted or Discerning: Voter Turnout in Post-Communist Countries. The Journal of Politics 71(2): 473-491.

- Pierson, P. (2001) New Politics of the Welfare State. Oxford: Oxford University Press.

- Przeworski, A. (2008) The Poor and the Viability of Democracy. In: A. Krishna (eds.) Poverty, Participation, and Democracy: A Global Perspective. New York: Cambridge University Press, 125-146.

- Quinn, G.P. and Keough, M.J. (2002) Experimental Design and Data Analysis for Biologists. Cambridge: Cambridge University Press.

- Schäfer, A. and Schoen, H. (2013) Mehr Demokratie, aber nur für wenige? Der Zielkonflikt zwischen mehr Beteiligung und politischer Gleichheit. Leviathan 41(1): 94-120.

- Schattschneider, E. E. (1960) The Semisovereign People: A Realist's View of Democracy in America. New York: Holt, Reinhart, and Winston.

- Schlozman, K.L., Verba, S. and Brady, H.E. (1999) Civic Participation and the Equality Problem. In: Skocpol, T. and Fiorina, M.P. (eds.) Civic Engagement in American Democracy. Washington: Brookings Institution Press, pp. 427-60.

- Schlozman, K.L., Page, B.I., Verba, S., and Fiorina, M. P. (2005) Inequalities of Political Voice. In: Jacobs, L., and Skocpol, T. (eds.) Inequality and American Democracy. New York: Russell Sage Foundation, pp. 19-87.

- Skrondal, A. and Rabe.Hesketh, S. (2009) Prediction in multilevel generalized linear models. Journal of the Royal Statistical Society 172(3): 659-687.

- Snijders, T.A.B., and Bosker, R.J. (1999) Multilevel Analysis: An Introduction to Basic and Advanced Multilevel Modelling. London: Sage Publisher. 
- Solt, F. (2008) Economic Inequality and Democratic Political Engagement. American Journal of Political Science, 52(1): 48-60.

- Solt, F. (2010) Does Economic Inequality Depress Electoral Participation? Testing the Schattscheider Hypothesis. Political Behavior 32: 285-301.

- Solt, F. (2015) Economic Inequality and Nonviolent Protest. Social Science Quarterly 96(5): 1314-1327.

- Solt, F. (2016) The Standardized World Income Inequality Database. Social Science Quarterly, first published online DOI: 10.1111/ssqu.12295.

- Streeck, W., and Mertens, D. (2013) Public Finance and the Decline of State Capacity in Democratic Capitalism. In: A. Schäfer and W. Streeck (eds.) Politics in the Age of Austerity. Cambridge: Polity Press, pp. 26-58.

- Thomassen, J.J.A. (1989). Economic crisis, dissatisfaction, and protest. In: M.K. Jennings, J.W. van Deth et al. (eds.) Continuities in Political Action. A Longitudinal Study of Political Orientations in Three Western Democracies. Berlin, New York: de Gruyter.

- Tóth, I.G., Horn, D. and Medgyesi, M. (2014) Rising Inequalities: Will Electorates Go for Higher Redistribution? In: B. Nolan, W. Salverda, D. Checchi, I. Marx, A. Mcknight, I.G. Tóth, H.G. van de Werfhorst (eds.) Changing Inequalities in Rich Countries. Analytical and Comparative Perspective. Oxford: Oxford University Press, pp. 11-47.

- Uslaner, E.M. and Brown, M. (2005) Inequality, trust, and civic engagement. American Politics Research 33: 868-894.

- Verba, S. Nie, N.H. and Kim, J. (1978) Participation and Political Equality: A Seven-Nation Comparison. New York and London: Cambridge University Press.

- Verba, S., Schlozman, K., and Brady, H. (1995) Voice and Equality: Civic Voluntarism in American Politics. Cambridge: Harvard University Press.

- Verba, S., Burns, N., and Schlozman, K.L. (2003) Unequal at the Starting Line: Creating Participatory Inequalities across Generations and among Groups. The American Sociologist 34(1-2): 45-69.

- Zuckin, C., Keeter, S. Andlina, M., Jenkins, K. and Delli Carpini, M.X. (2006) A New Engagement? Political Participation, Civic Life, and the Changing American Citizen. New York: Oxford University Press.

- Wolfinger, R. and Rosenstone, S. (1980) Who Votes? New Haven: Yale University Press. 
- Wuensch, K.L. (2011) Interaction Significant, Simple Main Effects Not Significant. Available at: http://core.ecu.edu/psyc/wuenschk/StatHelp/InteractionSignificant_SimpleMainsNot.docx 